1 Delhi, India

2 London, UK

indiastoryagency@gmail.com Cite this as: BMJ 2021;375:n2569 http://dx.doi.org/10.1136/bmi.n2569 Published: 03 November 2021

\title{
HEALTH AND DEVELOPMENT
}

\section{Afghanistan's doctors urge world to put politics and prejudice aside to save its healthcare}

\author{
Afghanistan was already struggling to respond to the needs of its population before the Taliban \\ takeover. Now the healthcare system is on the brink of collapse, and medics say the world must \\ work with the Taliban if it is to help, write Geetanjali Krishna and Sally Howard
}

\section{Geetanjali Krishna, ${ }^{1}$ Sally Howard ${ }^{2}$}

A fortnight ago Bashir (name changed to protect his identity), a hospital doctor in Kabul, decided to stop practising medicine.

"Before the Taliban took over, we hadn't been paid for three months," he says. "But how is a doctor expected to administer medical care without medicines and equipment?"

He reports seeing dozens of patients die for the want of routine dialysis, chemotherapy, and surgery. "If this is medical infrastructure in the capital of the country, imagine what must be happening in its remote, mountainous areas," Bashir says.

On 25 August, the World Bank halted funding for health and development in Afghanistan.

This came just a day after the Islamic fundamentalist group took hold of the capital, Kabul, and days before the US military completed its withdrawal from the country. Germany and the wider European Union also froze development funds, and the international designation of the Taliban as a terrorist organisation, as well as US and UN sanctions, have made it legally impossible for other foreign countries to continue to send aid.

By 29 September, WHO reported that just $17 \%$ of Afghanistan's 2300 or so health facilities-previously supported by the World Bank-remained fully functional. ${ }^{1}$ Two thirds had run out of essential medicines. The country's covid-19 response capacity has also sharply declined, and almost half of children are at risk of malnutrition (box 1).

Box 1: Women and children at risk

Elisabeth Kleipool, of the KIT Royal Tropical Institute, says that Afghan women are not accessing healthcare as they are afraid to leave their homes because of the Taliban's strict interpretation of Sharia law and that midwives are also staying at home. "A drop in skilled birth attendance rates will inevitably increase maternal mortality and newborn mortality rates," she says.

Afghanistan's maternal mortality rates had fallen from 1600 maternal deaths per 100000 births in 2001 to 638 maternal deaths per 100000 births in 2021, which nevertheless remains one of the highest maternal mortality rates in the world. ${ }^{8}$ Before the takeover, the country's hospitals were performing over 180 Caesarean sections, doing up to 500 routine and emergency operations, and immunising about 500 children a day, although services were already interrupted by conflict and insecurity.
Afghanistan continues to be one of the deadliest countries in the world for children, with children routinely recruited for combat and an estimated 33000 killed or maimed in the past 20 years. ${ }^{9}$ Half of the under 5 s are malnourished, and this will worsen in the immediate future, warns MSF's Yves Wailly.

"After the freeze on funds for healthcare by almost all foreign relief agencies and governments, healthcare facilities across Afghanistan are collapsing," Wahid Majrooh, former health minister of Afghanistan, told The BMJ. "I have seen patients in urgent need of dialysis being turned away as hospitals in Kabul do not have basic consumables."

He admits to being "very happy and relieved" to have left his office on 21 September. The situation on the ground is dire, says Majrooh. "Doctors, contractors and hospitals have not been paid for months, are continuing to call me to demand payments, and citizens are unable to access any sort of healthcare."

Shafi Ullah Nisar, a junior doctor who worked until recently at Khost Medical Information and Healthcare Centre in eastern Afghanistan, went unpaid for weeks before he stopped working. He is now awaiting news from the Taliban government as to whether he can resume work, but he worries this hiatus is a setback for the progress made in child immunisations and the treatment of tuberculosis in the past five years.

"We urgently need medical supplies and medicines, especially antimalarial and tuberculosis drugs," says Nisar. "For that, we need international aid."

\section{Fragile infrastructure}

Since 2003, under the World Bank funded Sehatmandi Project, international and local non-governmental organisations have been responsible for the delivery of health services through regional contracts. ${ }^{2}$ In 2018 and 2019, Afghanistan's health sector saw annual investments of over $\$ 1 \mathrm{bn}$, which ran some 3600 health facilities and more than 32 ooo health professionals.

"Despite [the funding] Afghanistan had a very fragile system, which was under-resourced, underfunded and understaffed," says Yves Wailly, who is coordinating the Afghanistan response for Médecins Sans Frontières (MSF). At the last count, Afghanistan had 2.78 doctors per 10 ooo people, compared with 
around 20 doctors per 10000 people in high income countries. ${ }^{3}$

Even before the August takeover, Afghan medics worked under constant fear of violence. According to WHO, more attacks occurred from January to August 2021 (42 incidents) than in the same period in 2020 ( 31 incidents). 4

Aliya Haidari, a former nurse in a maternity hospital in Kabul, describes working with a hovering Taliban presence. "One night, a woman in her twenties was brought to us, bleeding heavily after a miscarriage-her fourth pregnancy in five years," she told The BMJ. "She was too far gone for us to save. She was from the Taliban and her family blamed us for her death." Haidari and the doctor on duty that night received several threats, and she lived in fear until she managed to escape to India in 2017.

And then, covid-19.

The covid-19 pandemic and the political instability linked to the pull-out of American troops deepened existing fissures in Afghanistan's healthcare system, Majrooh says. "For almost two months before the Taliban took control, the government had diverted all its funds to the military," he says, adding that the Afghanistan government had not created a separate budget to deal with the pandemic.

“Oxygen supplies ran out, testing kits were in short supply, covid hospitals had no funds to pay doctors' salaries... it was very frustrating," he told The BMJ, adding that the health ministry had to use its salary budget to buy medicines before those funds also ran out.

The country's weak healthcare infrastructure was overwhelmed when a third wave of covid-19 swept across the country in May, reaching a peak at a rolling seven day average of 1721 cases a day, according to Johns Hopkins University. Afghanistan has an official death total of 7214 to date, but figures are thought to be a considerable underestimation given the difficulties in data collection and reporting. In most Afghan provinces there is no possibility of securing a covid-19 test, meaning samples for testing have to be transported to the capital, with transportation disrupted by recent political instability.

With the expected closure of health facilities due to a cessation of aid funding, only $3 \%$ of the 1318 covid-19 isolation beds in Afghanistan remain functional at the time of writing. MSF has a covid-19 isolation centre that works outside the government system and is, for now, still functioning. The non-governmental organisation believes the current wave is abating, "but we are on standby for a likely fourth wave," says Wailly.

\section{The road ahead}

On 13 September, the US announced nearly $\$ 64 \mathrm{~m}$ in humanitarian assistance for Afghanistan. ${ }^{5}$ Majrooh says this will fund the healthcare system for four months, although he anticipates it will take several weeks for monies to be made available. A further $\$ 15 \mathrm{~m}$ is due in October from the Geneva based Global Fund to Fight AIDS, ${ }^{6}$ and in November UN Central Emergency Response Fund funding of $\$ 45 \mathrm{~m}$ is expected.

But this is a fraction of what WHO estimates is needed. The 2021 update of the Afghanistan health plan, ${ }^{7}$ authored by the United Nations Office for the Coordination of Humanitarian Affairs, requested $\$ 1.3 \mathrm{bn}$ to reach 15.7 million people in need of life saving support to deal with the fallout from decades of conflict, recurrent natural disasters, and covid-19.
MSF has an annual budget of \$35m for Afghanistan. Dutch non-governmental organisation HealthNet TPO runs healthcare services in three Afghan districts (Kunar, Laghman, and Nangarhar), including childhood immunisation services, malnutrition interventions, and detection and prevention of tuberculosis and malaria, plus a 120 bed covid-19 hospital in Kabul. Its programme manager, Willem Reussing, told The BMJ that with World Bank funding frozen, HealthNet TPO's health facilities are running out of medicines, oxygen, and fuel for generators and ambulances and its staff have not received their salaries for three months.

Nadia Akseer, a diaspora Afghan scientist at Johns Hopkins Bloomberg School of Public Health, is campaigning for urgent humanitarian intervention in Afghanistan on public health grounds. "We encourage the World Bank and everyone else who has supported Afghanistan's healthcare system to be more innovative: can contracts and the money be given directly to the NGOs [non-governmental organisations] rather than the Taliban government?" she says. Although she adds that "we need to have a dialogue with the Taliban and we need to share health data with the Taliban: we can no longer afford not to."

Elisabeth Kleipool, a global health specialist at the Dutch non-profit KIT Royal Tropical Institute, says that before the takeover officials in regions already under Taliban control, including Kandahar and districts in Badakhshan and Sar-e Pol provinces, "tolerated" the Sehatmandi Project, and that this gives her hope for cooperation.

She believes that external governments should make public health their absolute priority, and that means working with the Taliban. "We need to keep structures in place as much as possible and keep services open for Afghan people," says Kleipool. "Whether we do that through governments dealing with the Taliban or dealing with NGOs is a political matter that needs to be quickly resolved."

Some doctors, such as Shafi Ullah Nisar, hope the Taliban takeover will end the instability that has afflicted his region for the past decade. The immediate future, however, looks bleak.

Shah Abdullah Qureshi, a final year medical student at Rokhan Medical University in Jalalabad, 90 miles east of Kabul, has not attended classes in months. Because of a mass exodus of medical professionals there are no teachers left to teach the students, he says, nor are there doctors or even medicines left to dispense.

"My request to donors is to help restore funding for medicines and food supplies," says Qureshi. "If the world does nothing for political reasons, Afghanistan's people will drown.”

Competing interests: We have read and understood the BMJ's policy on declaration of interests and have no relevant interests to declare.

Commissioning and peer review: Commissioned; not externally peer reviewed.

United Nations. Afghanistan: Rapid decline in public health conditions, WHO warns. 29 Sep 2021. https://news.un.org/en/story/2021/09/1101742.

2 World Bank. Afghanistan Sehatmandi Project. 2021. https://projects.worldbank.org/en/projectsoperations/project-detail/P160615.

3 World Health Organization. Global Health Observatory. Medical doctors (per 10000 population) 2021. https://www.who.int/data/gho/data/indicators/indicator-details/GHO/medical-doctors-(per10-000-population).

$4 \quad$ World Health Organization. Attacks on health care in Afghanistan (January to August 2021). 2021 https://www.humanitarianresponse.info/sites/www.humanitarianresponse.info/files/documents/files/afg-attacks_on_health_care_-_jan-august-2021-final.pdf.

USAID. The United States announces nearly $\$ 64$ million in additional humanitarian assistance for Afghanistan. 13 Sep 2021. https://www.usaid.gov/news-information/press-releases/sep-132021-united-states-nearly-64-million-additional-humanitarian-assistance-afghanistan.

6 The Global Fund. Global Fund and UNDP join efforts to maintain access to essential health services in Afghanistan. 6 Oct 2021. https://www.theglobalfund.org/en/news/2021-10-06-global-fundand-undp-join-efforts-to-maintain-access-to-essential-health-services-in-afghanistan 
7 OCHA Services. Afghanistan: Humanitarian response plan (2018-2021)-2021 revision. 2021. https://www.humanitarianresponse.info/en/operations/afghanistan/document/afghanistan-humanitarian-response-plan-2018-2021-2021-revision.

8 United Nations Population Fund. Midwives on the front lines working to reverse Afghanistan's high maternal death rate. 21 Oct 2020. https://www.unfpa.org/news/midwives-front-lines-

working-reverse-afghanistans-high-maternal-death-rate.

9 Save the Children. One child killed or maimed every 5 hours over 20 years of war in Afghanistan 31 Aug 2021. https://www.savethechildren.net/news/one-child-killed-or-maimed-every-5-hoursover-20-years-war-afghanistan. 